\title{
Population dynamics of Cymodocea nodosa under future ocean scenarios.
}

\author{
${ }^{1,2}$ Mishra, A.K., \\ ${ }^{1}$ Marine plant ecology research group (ALGAE), Centre for Marine Sciences (CCMAR), \\ University of Algarve, Faro, 8005-139, Portugal \\ ${ }^{2}$ Marine Biology and Ecology Research Centre, Davy Building, University of Plymouth, \\ Plymouth, PL48NA, UK
}

Corresponding author: amritkumarmishra@gmail.com

\begin{abstract}
Rising carbon dioxide $\left(\mathrm{CO}_{2}\right)$ concentrations in the atmosphere will increase the average $p \mathrm{CO}_{2}$ level in the world oceans, which will have a knock-on effect on the marine ecosystem. Coastal seagrass communities are predicted to benefit from the increase in $\mathrm{CO}_{2}$ levels, but long-term effects of elevated $\mathrm{CO}_{2}$ on seagrass communities are less understood. Population reconstruction techniques were used to investigate the population dynamics of Cymodocea nodosa meadows, exposed to long term elevated $\mathrm{CO}_{2}$ at volcanic seeps off Greece and Italy. Effect of elevated $\mathrm{CO}_{2}$ was noticed on the growth, morphometry, density, biomass and age structure at $\mathrm{CO}_{2}$ seeps than reference sites. Above to below ground biomass ratio of $C$. nodosa were higher at $\mathrm{CO}_{2}$ seeps. The shoot age and shoot longevity of plants were lower at seeps. The present recruitment (sampled year) of the seagrass were higher than long-term average recruitment of the communities near the seeps. Carbon to nitrogen ratios (\%DW) and annual leaf production of $C$. nodosa were higher in leaves at seeps. This study suggests under long-term $\mathrm{CO}_{2}$ enrichment $\mathrm{C}$. nodosa production increases, but the plant survival rate decreases because of other co-factors such as nutrient availability and trace metal toxicity. Therefore, along with high $\mathrm{CO}_{2}$ other factors must be taken into consideration while predicting effects of future $\mathrm{CO}_{2}$ concentrations.
\end{abstract}

Keywords: Reconstruction techniques, volcanic seeps, elevated $\mathrm{CO}_{2}$, carbon metabolism 


\section{Introduction:}

The ocean's absorption of anthropogenic $\mathrm{CO}_{2}$ emissions (over 35 Giga tonnes of $\mathrm{CO}_{2}$ per year, (IPCC, 2014) has already lowered the mean ocean surface $\mathrm{pH}$ by 0.1 units since preindustrial values, with a predicted further decrease of 0.3- 0.4 units by the end of this century (IPCC, 2014). These on-going changes are expected to intensify in the future with potentially significant, but variable effects on marine organisms depending on their sensitivity (Hendrick et al., 2010; Kroeker et al., 2010). Calcifying organisms are more susceptible to ocean acidification than non-calcifying organisms (Suggett et al., 2012), even though their responses to ocean acidification are dependent on the taxonomic group and their developmental stages (Hendrick et al., 2010; Kroeker et al., 2010). Realisation of the key role of seagrass in coastal ecosystems has fostered ever growing efforts to quantify their annual productivity and growth dynamics. (Duarte et al., 1994). Seagrasses, as many macro algal species, are notably tolerant to $\mathrm{CO}_{2}$ increases and may even benefit from it (Koch et al., 2013). In the current $\mathrm{CO}_{2}$ levels, seagrasses are dissolved inorganic carbon (DIC) limited as they are inefficient in utilising bicarbonate (Invers et al., 2001).

Hence, under increased $\mathrm{CO}_{2}$ conditions, it is expected seagrasses will increase utilization of $\mathrm{CO}_{2}$ (Beer et al. 1996) resulting in increased photosynthesis and consequently growth and productivity (Koch et al., 2013, Russel et al., 2013). Despite these predictions, the real-time studies conducted overtime both ex-situ with high $\mathrm{CO}_{2}$ and in-situ at natural $\mathrm{CO}_{2}$ seeps on seagrasses not completely support this expectation. For example, the photosynthetic activity of Cymodocea nodosa was stimulated by the low $\mathrm{pH}$ at natural $\mathrm{CO}_{2}$ seeps of Vulcano, with significant increase in chlorophyll-a content of leaves, maximum electron transport rate and compensation irradiance (Apostolaki et al., 2014). Low pH promoted productivity, but was not translated into biomass production, probably due to nutrient limitation, grazing or poor environmental conditions (Apostolaki et al., 2014). Similar results were obtained by Alexandra et al. (2012) for C. nodosa grown for five months under high $\mathrm{CO}_{2}$ conditions. On the other hand, the biomass and net primary production of Halophila ovalis and Cymodocea serrulata increased near the $\mathrm{CO}_{2}$ seeps, whereas the abundance of species increased only for $C$. serrulata, suggesting species specific response to elevated $\mathrm{CO}_{2}$ (Russell et al., 2013). Long term elevated $\mathrm{CO}_{2}$ experiments on Zostera marina for over one year showed greater reproductive outputs, increased below ground biomass and shoot density (Palacios and Zimmerman, 2007), whereas short term experiments resulted in increased photosynthetic rate and shoot productivity (Zimmerman et al., 1997). In contrast, experiments 
on Cymodocea serrulata have shown no enhancement in productivity at higher $\mathrm{CO}_{2}$ as they are carbon saturated in current $\mathrm{CO}_{2}$ concentrations (Schwarz et al., 2000). Recent $\mathrm{CO}_{2}$ enrichment studies on three tropical seagrass species showed a significant increase in net productivity with increase in $\mathrm{CO}_{2}$ levels, but a different growth rate between species was noticed due to varying strategies of carbon allocation among species (Ow et al., 2015).

Studies on natural $\mathrm{CO}_{2}$ seeps suggest that seagrass species can be adapted to survive and live under elevated $\mathrm{CO}_{2}$ conditions (Hall Spencer et al., 2008, Fabricius et al., 2011 and Takahashi et al., 2016). Much of the natural $\mathrm{CO}_{2}$ seeps of Europe are concentrated in the Mediterranean Sea (Dando et al.,1999). In the Mediterranean Sea, most known seeps are concentrated in the shallow waters of the active volcanic arcs in Aegean Seas and are usually of the gas hydrothermal type due to the large volume of gas released (Dando et al., 1999). These natural $\mathrm{CO}_{2}$ seeps provide future oceanic conditions (Hall Spencer et al.,2008; HallSpencer and Rodolfo-Metalpa, 2009) and are expected to affect seagrass communities due to changes in the physical and chemical features of seawater and sediments with possibly large effects on functioning features (Vizzini et al., 2010). In these conditions the growth and age structure of the seagrass Cymodocea nodosa in these seeps have not been investigated. The seagrass Cymodocea nodosa is an endemic species that supports highly complex and biodiverse climax communities in the Mediterranean Sea (Mazzella et al., 1986). Nevertheless, the effects of hydrothermal $\mathrm{CO}_{2}$ gas release associated to explosive volcanism activity on seagrass productivity has been studied (Vizzini et al., 2010). How these changes will affect higher levels of biological organization, such as seagrass population dynamics (e.g. shoot recruitment rate), is less studied.

The objective of this work is to assess for the first time the long-term responses of the population dynamics and production of seagrass, $C$. nodosa exposed to elevated $\mathrm{CO}_{2}$ levels. Populations in the vicinity and away from the influence of volcanic seeps were compared. $\mathrm{CO}_{2}$ seep sites have been used to assess the long-term effects of elevated $\mathrm{CO}_{2}$ on benthic marine ecosystems and respective underlying mechanisms (Hall-Spencer et al., 2008, Fabricius et al., 2011, Vizzini et al., 2013, Enochs et al., 2015). However, other cofounding factors related to the volcanic seeps, such as the emissions of heavy metals (Dando et al., 1999, Vizzini et al., 2013, Kadar et al., 2013) and sulphide (Dando et al., 1999, Boatta et al.,2013) may influence the plants and population responses to elevated $\mathrm{CO}_{2}$. These are very variable among seeps (Dekov et al., 2004, Varnavas et al., 2005) whereas the major $\mathrm{CO}_{2}$ composition of emissions is constant. To cope with possible confounding factors of the 
effects of $\mathrm{CO}_{2}$ on the population dynamics of $C$. nodosa, we replicated the sampling effort in three seeps, two at the island of Milos in Greece and one at Vulcano island in Italy, to consider only the common responses as effects of elevated $\mathrm{CO}_{2}$.

\section{Methods:}

Study sites

Milos Islands, Greece

Paleochori Bay (36.67 N, 24.51 E) and Adamas thermal stations (36.70 N, 24.46 E) are part of Milos island (Fig.1A). Extensive submarine venting occurs offshore, from the intertidal to depths of more than $100 \mathrm{~m}$ over a $34 \mathrm{~km}^{2}$ area of seabed (Dando et al.,1999). The released gases are $95 \% \mathrm{CO}_{2}$ with some $\mathrm{H}_{2} \mathrm{~S}, \mathrm{CH}_{4}$ and $\mathrm{H}_{2}$ (Dando et al., 1999).

Vulcano, Italy

We sampled Levante Bay (38.4 N, 15.0 E) off Vulcano island (Fig. 1B). Some parts of this bay are well-suited for studies of the effects of increased $\mathrm{CO}_{2}$ levels (Boatta et al., 2013) despite areas with elevated $\mathrm{H}_{2} \mathrm{~S}$ and metals (Vizzini et al., 2013). The main underwater gas seeps are located along southern and western shores of the bay at $<1 \mathrm{~m}$ depth (Boatta et al., 2013). Total $\mathrm{CO}_{2}$ output is about 3.6 tonne $\mathrm{d}^{-1}$ (Inguaggiato et al., 2012), and the underwater gas emissions are $97-98 \% \mathrm{CO}_{2}$ with $2.2 \% \mathrm{H}_{2} \mathrm{~S}$ close to the seeps, decreasing to less than $0.005 \% \mathrm{H}_{2} \mathrm{~S}$ towards the north-eastern part of the bay, where most ocean acidification research has been located (Capaccioni et al., 2001; Milazzo et al., 2014). There is a step gradient in carbonate chemistry with $\mathrm{pH} 5.65$ at the main gas seeps increasing to $\mathrm{pH}$ 8.1 , which is typical for present day Mediterranean surface seawater, at $>350 \mathrm{~m}$ from the seeps (Boatta et al., 2013). Cymodocea nodosa were absent at the main vents.

In each location, two sites were established where well developed populations of $C$. nodosa were present, a high $\mathrm{CO}_{2}$ site near the seeps and a reference site away from the influence of the vent. Reference and $\mathrm{CO}_{2}$ seep sites were established at the same depths, under similar hydrodynamics conditions. Overall, $C$. nodosa meadows sampled were at shallow $(<5 \mathrm{~m})$ depth.

\section{Water sampling:}

Water samples $(n=5)$ were collected at $\mathrm{CO}_{2}$ seeps and reference sites in $100 \mathrm{ml}$ Winkler bottles fixed with $20 \mu \mathrm{l}$ mercury chloride in the field, stored in the dark and 
transported to the laboratory for total alkalinity (TA) and dissolved inorganic carbon (DIC) analysis. The $\mathrm{pH}$ (using $\mathrm{pH}$ meter, Titrino Methron) and temperature of the water samples were measured in the field immediately after collection. In the laboratory $\mathrm{pH}$ and temperature were measured again and $80 \mathrm{ml}$ of water sample was used in Lab Titrino analyser (Dickson et al. 2007) for the analysis of TA. Temperature, $\mathrm{pH}$ and TA data were used to calculate the other carbonate parameters $\left(\mathrm{CO}_{2}, \mathrm{HCO}_{3}{ }^{-}\right.$, aragonite saturation state, etc.) using $\mathrm{CO}_{2} \mathrm{Sys}$ program (Pierrot and Wallace.2006).

\section{Seagrass sampling and analysis:}

The meadow density and biomass, the rhizome growth and production, the morphometric characteristics of the plants, the population age structure and derived population dynamics (long-term average recruitment, present recruitment and population growth rates) and the total $\mathrm{C}$ and $\mathrm{N}$ contents of plants were characterized in $\mathrm{CO}_{2}$ seeps and reference sites. Reconstruction techniques, an indirect measure of plant growth history and population dynamics changes (Duarte et al., 1994; Fourqurean et al. 2003), were used to evaluate the $C$. nodosa responses to the different environmental conditions caused by the seeps. It was hypothesized that increased $\mathrm{CO}_{2}$ promote higher plant growth, higher meadow production, and thus higher population dynamics.

Ten $C$. nodosa samples were collected from each site with a $20-\mathrm{cm}$ diameter core (15 cm in Greece) into a depth of about $30 \mathrm{~cm}$ in May 2013 in Italy and May 2014 in Greece. The sediment was carefully rinsed off to prevent the modular sets disconnecting from each other and to keep the rhizome mat intact as required for the reconstruction of seagrass dynamics (Duarte et al., 1994). In each sample, the number of both shoots and apicals was counted to estimate the density of shoots and of physically independent individuals. The age of $C$. nodosa shoots was estimated by counting the number of leaf scars on the vertical rhizomes plus the number of leaves in each shoot multiplied by the leaf plastochrome interval (PI). To estimate the PI of each study site, i.e., the time needed to produce a new leaf, the sequence of average internodal length of $C$. nodosa shoots collected with the cores plus additional plants collected by hand was plotted. Then a $30 \%$ running average was applied to filter short-term seasonal variability and the difference in the number of vertical leaf scars between two consecutive length modes was counted. The modes represent annual growth periods and thus the average number of leaf scars produced between modes was averaged to estimate the leaf PI of the population (Short et al. 2001). The PI estimates of Cymodocea nodosa were 29.3 for all three locations off Greek and Italy islands. 
To estimate the vertical and horizontal rhizome elongation rates the length of both the vertical and horizontal rhizomes between consecutive shoots was measured and the number of both vertical and horizontal internodes between consecutive shoots was counted (see Duarte et al., 1994 for details of method). The number of leaves per shoot were measured from intact shoots in each sample $(n=10)$. The horizontal and vertical rhizome production rates were estimated by multiplying the elongation rates (vertical or horizontal) by density (shoots or apicals), by the specific dry weight of rhizomes (vertical or horizontal) and by the dry weight contents of $\mathrm{C}$ (vertical or horizontal). Annual leaf production of each population was calculated as the product of the number of leaves annually produced per shoot, the shoot density, the mean specific dry weight of fully developed leaves and their $\mathrm{C}$ content.

The leaves, vertical rhizomes, horizontal rhizomes and roots were separated and dried for $48 \mathrm{~h}$ at $60^{\circ} \mathrm{C}$ for biomass and production estimates. Dried plant material (leaves, vertical rhizomes, horizontal rhizomes and roots) was grounded and analysed for CHN contents in a CHN analyser (EA 1110 Model, Elemental Microanalysis Ltd, Oakhampton, Devon, UK).

The long-term average recruitment (R) was estimated from the shoot age structure using the general model: $\mathrm{N}_{\mathrm{x}}=\mathrm{N}_{0} e^{-\mathrm{Rx}}$, where $\mathrm{N}_{\mathrm{x}}$ is the number of shoots in age class $\mathrm{x}, \mathrm{N}_{0}$ is the number of shoots recruited into the population; assuming that mortality and recruitment have had no trend over the lifespan of the oldest shoots in the population, i.e. have remained constant over the lifespan of the oldest shoots, with year to year random variation around some mean value of mortality and recruitment (Fourqurean et al. 2003, Duarte et al. 2005). The recruitment for the current year of sampling $\left(\mathrm{R}_{0}\right)$ was estimated using the method described by Duarte et al., (1994). The population growth rate $(r)$ was estimated as: $r=\mathrm{R}_{0}-$ $\mathrm{M}$, where $\mathrm{M}$ is the long-term mortality rate, which equals the long-term recruitment rate $(\mathrm{R})$ under the assumptions of near steady state (Fourqurean et al., 2003). Population was considered growing if $r$ is positive $\left(\mathrm{R}_{0}>\mathrm{R}\right)$, shrinking if $r$ is negative $\left(\mathrm{R}_{0}<\mathrm{R}\right)$, or with the same trajectory pattern if $R_{0}$ is not significantly different from $R$ (Fourqurean et al., 2003).

\section{Statistical analysis:}

Significant differences in biomass, density, production and plant morphometry among sites $\left(\mathrm{CO}_{2}\right.$ seeps and reference) and locations (Adamas, Paleochori and Vulcano) were investigated using two-way ANOVA, after testing for homogeneity of variances and normality of distribution. The Tukey's multiple comparison test was applied to determine significant differences between factor levels. When ANOVA assumptions were not verified, 
comparison of data sets were performed using the non-parametric test of Kruskal-Wallis and the post hoc Dunn's test. Log transformations of variables were performed where needed.

The species vertical and horizontal rhizome elongation, and the population recruitment rates were obtained considering all replicates in each site. The t-test for the difference between two regression lines was used to compare the vertical rhizome elongation rates as these are equal to the slopes of the linear regression between age and size of rhizomes. Statistical analyses were not performed for the horizontal rhizome elongation rate, because just one value was obtained for each site. The confidence limits of the exponential decay regression model used to estimate the long-term average recruitment rate $(\mathrm{R})$ allowed its statistical comparison to the present recruitment rate $\left(\mathbf{R}_{0}\right)$ as described in Fourqurean et al., (2003). Significant differences of the long-term recruitment rate among sites were tested using one-way ANOVA. Significance levels was considered at $p<0.05$ (Sokal and Rohlf, 2012).

\section{Results:}

Seawater carbonate chemistry values (mean \pm se) of the three sites Adamas, Paleochori and Vulcano are presented in Table 1. At all stations, the $p \mathrm{CO}_{2}$ concentration was higher (737 \pm $158-2457.9 \pm 1.87)$ and $\mathrm{pH}$ lower $(7.98 \pm 0.08-7.50 \pm 0.04)$ near the $\mathrm{CO}_{2}$ seeps (Table 1$)$. The reference stations (Reference) lying further away from the $\mathrm{CO}_{2}$ seeps showed almost two times lower concentrations of $\mathrm{CO}_{2}$ except for Vulcano. DIC (3474.03 \pm 4.55$)$ and $\mathrm{CO}_{2}(2377 \pm$ 37) concentrations were higher at Adamas and lower at Vulcano.

Significant response of $C$. nodosa to elevated $\mathrm{CO}_{2}$ was noticed on density and biomass at all three $\mathrm{CO}_{2}$ seeps. Both shoot and apex density, i.e. the number of physically independent plants was 1.3fold (shoot density) and 2.3fold (apex density) higher at $\mathrm{CO}_{2}$ seeps than reference stations, exceptions were shoot density at Vulcano and apex density at Adamas seep stations (Fig. 2). Both shoot (1322.00 166.20 no.m ${ }^{-2}$ ) and apex density $(299.40 \pm 37.70$ no. $\mathrm{m}^{-2}$ ) was higher at Adamas than Paleochori and Vulcano seep stations. Total biomass $\left(456.20 \pm 64.90 \mathrm{~g} \mathrm{DW} \mathrm{m}^{-2}\right)$, leaf biomass $\left(97.70 \pm 9.10 \mathrm{~g} \mathrm{DW} \mathrm{m}^{-2}\right)$ and horizontal biomass (155.10 $\pm 29.0 \mathrm{~g} \mathrm{DW} \mathrm{m}^{-2}$ ) were higher at seeps of Vulcano than Adamas and Paleochori stations, whereas above ground-below ground biomass ratio $\left(0.60 \pm 0.10 \mathrm{~g} \mathrm{DW} \mathrm{m}^{-2}\right)$ was higher at seeps of Paleochori (Fig. 2). Significant increase (>1.2-fold) in total biomass and leaf biomass was observed at Paleochori and Adamas seeps than reference stations, whereas 
for horizontal biomass this increase (>1.2-fold) was found at seeps of Paleochori and Vulcano. However, the highest total biomass recorded for Vulcano was 0.9-fold lower than reference station. The vertical rhizome biomass $\left(67.60 \pm 10.0 \mathrm{~g} \mathrm{DW} \mathrm{m}^{-2}\right)$ was significantly lower near the seeps than reference $\left(124.40 \pm 17.60 \mathrm{~g} \mathrm{DW} \mathrm{m}^{-2}\right)$ stations of Vulcano but significant increase of biomass was observed for Paleochori (1.9-fold) and Adamas (1.2fold). Significant effects of $\mathrm{CO}_{2}$ on plant morphology was observed on number of leaves and vertical rhizome. The number of leaves per shoot was higher at Adamas $\left(4.50 \pm 0.01\right.$ shoot $\left.^{-1}\right)$ and the vertical rhizome $(0.35 \pm 0.03-2.10 \pm 0.10 \mathrm{~cm})$ was shorter near all the seep stations (Fig.3).

Significant variation in density, biomass and morphometry of C. nodosa was observed between Greek and Italian sites (Adamas vs Vulcano, Paleochori vs Vulcano) but not between Greek sites (Adamas vs Paleochori), except for number of leaves which was significant between Greek sites and shoot density that did not vary among sites (Fig.3). Significant differences between apex density was found between Adamas vs Vulcano and for biomass between sites of Adamas vs Vulcano and Vulcano vs Paleochori. The vertical rhizome length and number of leaves varied significantly between Adamas vs Vulcano and Vulcano vs Paleochori (Fig.3).

Vertical elongation rate of $C$. nodosa was 1 to 1.2 -fold higher at $\mathrm{CO}_{2}$ seeps than reference stations at all sites and significant (see Appendix). Horizontal elongation rate was1 to 1.3-fold higher at seep than reference stations at all sites except for Vulcano $\mathrm{CO}_{2}$ seep station, where it was 0.7-fold lower than reference station (See Appendix).

The elemental content of carbon and $\mathrm{C}: \mathrm{N}$ ratios of $C$. nodosa leaves, rhizomes and roots showed that whenever there are significant differences, these reflect a carbon enrichment of tissues near $\mathrm{CO}_{2}$ seeps (Table 3). Significantly higher carbon content was observed near the seep in the leaves and roots at Adamas, leaves at Paleochori and leaves and rhizomes at Vulcano than reference stations. The only significant difference found in the tissues $\mathrm{N}$ content was in the rhizomes of Paleochori, where it was 4.2-fold lower near the seeps than reference station (Table 3). Significant differences in C: $\mathrm{N}$ ratios were observed in roots of Adamas, rhizomes of Paleochori and roots and rhizomes of Vulcano. Significant differences of $\mathrm{C}$ and $\mathrm{N}$ content in leaves among sites was found at Adamas vs Vulcano and Vulcano vs Paleochori. In the roots the $\mathrm{C}$ and $\mathrm{N}$ content was significant al all three sites (Table 3). The $\mathrm{C}$ : $\mathrm{N}$ content significant differences was found in the leaves and rhizomes at Adamas vs Paleochori and Vulcano vs Paleochori. 
The effects of elevated $\mathrm{CO}_{2}$ were also observed on $C$. nodosa rhizome and leaf production. The vertical rhizome production was 2.1 to 2.7 -fold higher and horizontal rhizome production were 1.3 to 2.9-fold higher at $\mathrm{CO}_{2}$ seep than reference stations (Fig.5). Highest vertical $\left(200.0 \pm 60.20 \mathrm{gCm}^{-2} \mathrm{y}^{-1}\right)$ and horizontal rhizome $\left(299.50 \pm 37.70 \mathrm{gCm}^{-2} \mathrm{y}^{-1}\right)$ production was found at Adamas and lowest at Vulcano seep stations. Annual leaf production

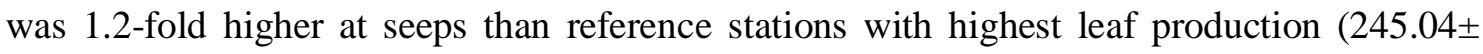
$26.68 \mathrm{gCm}^{-2} \mathrm{y}^{-1}$ ) found at Vulcano seep station (Fig.6). Leaf production of Vulcano and Adamas was 2.3-fold and 1.1-fold higher than Paleochori seep station. The vertical rhizome production was significantly different at Vulcano vs Adamas and Adamas vs Paleochori sites and for horizontal rhizome at all three $\mathrm{CO}_{2}$ seep sites. Significant differences for leaf production were found for Adamas vs Vulcano and Vulcano vs Paleochori (Fig.6).

The age structure of $C$. nodosa was significantly affected at $\mathrm{CO}_{2}$ seeps, as both the average shoot age (Fig.7) and shoot longevity, were lower near the seeps at all sites (Table 2). The lifespan of the oldest shoots was between seven to eight years at Vulcano, whereas at Paleochori and Adamas it varied between three to four years (Fig. 7). The present and longterm recruitments were always higher near the seeps, even though the differences were not statistically significant, except for Paleochori (Table 2). The age frequency distribution of $C$. nodosa showed a significant higher number of younger plants (1 and 2 years older) at the $\mathrm{CO}_{2}$ seeps, whereas the number of older plants (more than 3 years) were higher near the reference stations at all three sites (Fig.8).

The different variables analysed here for C. nodosa using reconstruction techniques responded differently between $\mathrm{CO}_{2}$ seep and reference stations among the three sites of Adamas, Paleochori and Vulcano of Greek and Italy islands. Significant interaction among stations and sites for variables (number of leaves, total biomass, horizontal rhizome biomass, above ground: below ground biomass, Leaves (\%C), Roots (\%C), Rhizomes (\%N), Rhizomes $(\mathrm{C}: \mathrm{N}))$ was observed at all three sites of Adamas, Paleochori and Vulcano. 


\section{Discussion:}

Population dynamics of $C$. nodosa near the shallow $\mathrm{CO}_{2}$ seeps of Greek (Adamas and Paleochori) and Italy(Vulcano) islands were positively affected under long term increased $\mathrm{CO}_{2}$ levels. The density, biomass, morphometry, age structure and production of C. nodosa showed positive response to elevated $\mathrm{CO}_{2}$ levels, although this response was variable among the three sites.

The high $\mathrm{pCO}_{2}$ level and low $\mathrm{pH}$ at the $\mathrm{CO}_{2}$ seeps of the Greek and Italy islands represented current (reference) and future 2100 (elevated $\mathrm{CO}_{2}$ ) scenarios, enabling us to assess the long-term effects of elevated $\mathrm{CO}_{2}$ on seagrass communities. Input of volcanic $\mathrm{CO}_{2}$ concentrations from the seeps, not only increased the dissolved $\mathrm{CO}_{2}$ concentration in the surrounding waters, but also increased the relative portion of dissolved $\mathrm{CO}_{2}$ to $\mathrm{HCO}_{3}$ - (Short and Neckles. 1999) with a positive effect on seagrasses, as observed for the vertical and horizontal rhizome productivity, apex and shoot density and biomass of $C$. nodosa found at all seeps investigated. Plants developing near the $\mathrm{CO}_{2}$-seeps expressed an increase in fitness confirming that seagrasses can thrive in predicted scenarios of global $\mathrm{CO}_{2} / \mathrm{OA}$ changes (HallSpencer et al. 2008; Russell et al. 2013). Boosted growth and production with proximity to $\mathrm{CO}_{2}$-seeps suggest that the increase in $\mathrm{CO}_{2}$ concentrations will favour the utilization of inorganic carbon sources, seagrasses being C limited (Invers et al., 2001; Apostolaki et al., 2014)

The distribution of $C$. nodosa around the seeps may be related to high level of patchiness of the seagrass meadow, which was evident during sampling. Apex density of $C$. nodosa were higher at all three $\mathrm{CO}_{2}$ seeps compared to reference sites, but the higher density was not transferred to significant patch expansion of seagrass meadows close to the seeps, even though $C$. nodosa can translocate itself to make meadows (Kraemer and Mazzella, 1999). Lack of $C$. nodosa meadows near the $\mathrm{CO}_{2}$ seeps can also be related to the associated geochemical features (e.g. toxic levels of trace elements) of individual $\mathrm{CO}_{2}$ seeps affecting the migration of meadow spatially. Increase in density at all three $\mathrm{CO}_{2}$ seeps and biomass (only at Greek $\mathrm{CO}_{2}$ seep sites) for $C$. nodosa coincides with a range of seagrass species, for instance density and biomass increased with increase in $\mathrm{CO}_{2}$ levels, for P. oceanica (HallSpencer et al., 2008), C. rotundata and C. serrulata (Fabricius et al., 2011b; Russell et al., 2013) and Zostera marina (Palacios and Zimmerman, 2007), whereas decrease in biomass for C. nodosa in Vulcano $\mathrm{CO}_{2}$ seeps coincides with the results of Russell et al., (2013) for Halophila ovalis implying species-specific response to increased $\mathrm{CO}_{2}$ levels in future oceans. 
Higher density at all three $\mathrm{CO}_{2}$ seeps and higher horizontal rhizome biomass of $C$. nodosa at Vulcano among three $\mathrm{CO}_{2}$ seeps, suggest, $C$. nodosa at these seeps are adjusted to their carbon utilization capacity to the dissolved inorganic carbon (both $\mathrm{CO}_{2}$ (aq) and $\mathrm{HCO}_{3}{ }^{-}$) concentrations of the surrounding water, similar results were obtained for T. testudinum in field and laboratory conditions (Durako.,1993). The low $\mathrm{pH}$ conditions were followed by increase in density (shoot and apex) of $C$. nodosa at all three $\mathrm{CO}_{2}$ seeps, compared to the reference sites, coinciding with results observed for $C$. rotundata and $C$. serrulata at Papua New Guinea $\mathrm{CO}_{2}$ seeps (Takahashi et al., 2016) and differing from previous results of $C$. nodosa at $\mathrm{CO}_{2}$ seeps of Vulcano (Apostolaki et al., 2014), whereas decrease of total biomass in Vulcano agrees with previous from the same area (Apostolaki et al., 2014). The above ground biomass was above $20 \%$ of total biomass at Greek and Italy $\mathrm{CO}_{2}$ seep sites, which agrees with findings for C. nodosa at Ischia seeps (Gianluigi et al., 2002), resulting in lower below ground biomass (lower than $80 \%$ ) of seagrass meadows in elevated $\mathrm{CO}_{2}$ levels. Our results of lower below ground biomass did not match with results from another seagrass species (Zostera marina) in $\mathrm{CO}_{2}$ enriched conditions (Welsh et al. 1997; Palacios and Zimmerman, 2007).

Carbon content in C.nodosa leaves increased at the $\mathrm{CO}_{2}$ seep stations at Paleochori and Adamas sites, and remained invaribale at Vulcano sites, which agrees with experimental results from $T$. testudinum and $T$. hemprichii which showed invaribale carbon content in $\mathrm{CO}_{2}$ enriched and reference conditions ( Campbell and Fourqurean et al., 2013: Jiang et al., 2010). The $\mathrm{N}$ content of the $C$. nodosa leaves $(1.67 \% \mathrm{DW} \pm 0.36)$ were low at Paleochori $\mathrm{CO}_{2}$ seep and were below the threshold $(1.8 \% \mathrm{DW})$ for $\mathrm{N}$ limitation in seagrass (Duarte. 1990) suggesting that nitrogen deficiency may have limited overall plant growth, whereas $\mathrm{N}$ content of C.nodosa leaves at Adamas $(1.85 \% \mathrm{DW} \pm 0.05)$ were not along the thresehold level and may have added to higher growth and density of plants at the Adamas $\mathrm{CO}_{2}$ seeps. In case of $C$. nodosa leaves at Vulcano even with higher $\mathrm{N}$ content, growth and density remained lower, similar results were obtained for $C$. nodos $a$ in experimental $\mathrm{CO}_{2}$ and nutrient enrichment conditions ( Khan et al., 2016). Simultaneously lower growth can be attributed to the epiphytic microalgae on seagrass leaves, which gets dominant during high $\mathrm{N}$ content, compete with the seagrass in production and eventually shade the seagrass leaves ( Valiela et al., 1997). Lower C: $\mathrm{N}$ ratios in leaves of the plants at all sites (Table 3) suggests that plants near the seeps utilize the available nitrogen rapidly relative to their carbon content (Duarte. 1990). As nutrient availability increases seagrass tissues, must have been become 
progressively enriched in nitrogen relative to the carbon content implying decreasing $\mathrm{C}: \mathrm{N}$ ratios, as found in rhizomes of all three $\mathrm{CO}_{2}$ seeps and roots of Vulcano seeps, whereas the opposite trends were observed in the roots of $C$. nodosa at Greek $\mathrm{CO}_{2}$ seeps (Table 3).

Significant interactions among stations and sites for C. nodosa variables (biomass, morphometry, carbon and nitrogen content) suggests that the effects of $\mathrm{CO}_{2}$ on these variables depends on the sites too, i.e., the levels of $\mathrm{CO}_{2}$ at these sites. This also indicates that positive response of biomass (total, horizontal and $\mathrm{Ag}: \mathrm{Bg}$ ), morphometry (no. of leaves) and carbon content (leaves and roots) to $\mathrm{CO}_{2}$ levels at the three sites are not entirely due to $\mathrm{CO}_{2}$ seeps but due to also the local environmental conditions of these seeps. Although there was an interaction among sites, ANOVA analysis (Tukey's test) indicated which were the sites that have significant effect of $\mathrm{CO}_{2}$ on $C$. nodosa variables.

The low rhizome elongation (ca. $4.27-10.6 \mathrm{~cm} \mathrm{year}^{-1}$ ) for $C$. nodosa at Adamas, Paleochori and Vulcano (ca.7.91 $\mathrm{cm}^{-1}$ year $^{-1}$ ) $\mathrm{CO}_{2}$ seeps suggested a reduced recruitment ( Duarte and Sand-Jensen, 1990) compared to other populations elsewhere (40 cm year ${ }^{-1}$; Marbà and Duarte, 1998). Increased growth (vertical and horizontal elongation) and production (vertical rhizome, horizontal rhizome and leaf) with proximity to $\mathrm{CO}_{2}$ seeps at all three locations suggests plants were $\mathrm{C}$ limited in current conditions in the world oceans (Zimmerman et al., 1997; Invers et al., 2001). Additionally, the Adamas, Paleochori and Vulcano seeps, apart from $\mathrm{CO}_{2}$ supplies, may also be enriched volcanic inputs such as trace elements, which above certain levels can be toxic (Vizzini et al. 2013) and along with low $\mathrm{pH}$ and depleted oxygen levels can deteriorate the chemical properties of nearby water and sediment and in turn affect the seagrass productivity negatively.

Our results represent an early assessment of seagrass $C$. nodosa response under long term $\mathrm{CO}_{2}$ enrichment using population reconstruction techniques as a tool. Comparison to similar studies of $C$. nodosa at other seeps suggests that seagrass response to naturally acidified conditions is not so straight forward as the response is species-specific and depends on the biogeochemical characteristics of the site. Clearly, further research on seagrass growth and production using reconstruction techniques in $\mathrm{CO}_{2}$ seeps in world oceans is necessary, keeping in mind the ecosystem services seagrass provides, their capacity to act as global carbon sink and their major role in mitigation of the elevated levels of $\mathrm{CO}_{2}$ in future oceans. 
Table 1

Seawater carbonate chemistry measurements at Adamas, Paleochori and Vulcano $\mathrm{CO}_{2}$ seeps calculated with $\mathrm{CO}_{2}$ Sys programme, using constants from Dickson and Millero, 1987, and $\mathrm{pH}$ in NBS scale.

\begin{tabular}{|c|c|c|}
\hline \multirow[b]{3}{*}{ pH (NBS scale) } & $\mathrm{CO}_{2}$ seeps & Reference \\
\hline & Adamas & \multirow[b]{2}{*}{$8.2 \pm 0.03$} \\
\hline & $7.5 \pm 0.04$ & \\
\hline$p \mathrm{CO}_{2}(\mu \mathrm{atm})$ & $2457.9 \pm 1.87$ & $405.5 \pm 1.65$ \\
\hline DIC $\left(\mu \mathrm{mol} \mathrm{kg}{ }^{-1}\right)$ & $3474.03 \pm 4.55$ & $1407.44 \pm 51.25$ \\
\hline \multirow[b]{2}{*}{ pH (NBS scale) } & Paleochori & \multirow[b]{2}{*}{$8.2 \pm 0.01$} \\
\hline & $7.9 \pm 0.01$ & \\
\hline$p \mathrm{CO}_{2}(\mu \mathrm{atm})$ & $884.3 \pm 3.07$ & $402.9 \pm 1.1$ \\
\hline DIC $\left(\mu \mathrm{mol} \mathrm{kg}{ }^{-1}\right)$ & $2738.39 \pm 16.49$ & $1396.14 \pm 48.69$ \\
\hline \multirow[b]{2}{*}{ pH (NBS scale) } & Vulcano & \multirow[b]{2}{*}{$8.17 \pm 0.05$} \\
\hline & $7.98 \pm 0.08$ & \\
\hline$p \mathrm{CO}_{2}(\mu \mathrm{atm})$ & $737 \pm 158$ & $427 \pm 68$ \\
\hline $\mathrm{DIC}\left(\mu \mathrm{mol} \mathrm{kg}{ }^{-1}\right)$ & $2377 \pm 37$ & $2244 \pm 40$ \\
\hline
\end{tabular}


Table 2

Age structure and population dynamics of Cymodocea nodosa shoots at $\mathrm{CO}_{2}$ seeps and reference sites of Greek (Adamas and Paleochori) and Italy (Vulcano) islands. Mean \pm Standard errors are presented for the shoot age. The exponential coefficient \pm standard errors of the exponential decay regression are presented for the long-term average recruitment rate (R). Different letters indicate significant difference between $\mathrm{CO}_{2}$ seeps and reference sites only for $\mathrm{R}$, ns= not significant. $\mathrm{P}$ values obtained from one-way ANOVA for Adamas $(\mathrm{p}=0.116)$, Paleochori $(\mathrm{p}=0.013)$ and Vulcano $(\mathrm{p}=0.105)$

\begin{tabular}{|c|c|c|}
\hline & \multicolumn{2}{|l|}{ Adamas } \\
\hline & $\mathrm{CO}_{2}$ seeps & Reference \\
\hline Shoot longevity (years) & 3.21 & 3.53 \\
\hline Long term avg. recruitment rate $\left(\mathrm{R}\right.$, year $\left.^{-1}\right)$ & $1.03 \pm 0.05^{\mathrm{ns}}$ & $0.90 \pm 0.05^{\mathrm{ns}}$ \\
\hline Present recruitment rate $\left(\mathrm{R}_{0}\right.$, year $\left.^{-1}\right)$ & 1.08 & 0.94 \\
\hline \multirow[t]{3}{*}{ Population growth rate $\left(\mathrm{r}\right.$, year $\left.^{-1}\right)$} & 0.05 & 0.04 \\
\hline & \multicolumn{2}{|l|}{ Paleochori } \\
\hline & $\mathrm{CO}_{2}$ seeps & Reference \\
\hline Shoot longevity (years) & 2.41 & 2.81 \\
\hline Long term avg. recruitment rate $\left(\mathrm{R}\right.$, year $\left.^{-1}\right)$ & $1.41 \pm 0.08^{\mathrm{a}}$ & $0.42 \pm 0.23^{b}$ \\
\hline Present recruitment rate $\left(\mathrm{R}_{0}\right.$, year $\left.^{-1}\right)$ & 1.54 & 0.52 \\
\hline \multirow[t]{3}{*}{ Population growth rate $\left(\mathrm{r}\right.$, year $\left.^{-1}\right)$} & 0.07 & 0.09 \\
\hline & \multicolumn{2}{|l|}{ Vulcano } \\
\hline & $\mathrm{CO}_{2}$ seeps & Reference \\
\hline Shoot longevity (years) & 7.14 & 8.27 \\
\hline Long-term avg. recruitment rate $\left(\mathrm{R}\right.$, year $\left.^{-1}\right)$ & $0.64 \pm 0.11^{\mathrm{ns}}$ & $0.37 \pm 0.05^{\mathrm{ns}}$ \\
\hline Present recruitment rate $\left(\mathrm{R}_{0}\right.$, year $\left.{ }^{-1}\right)$ & 0.65 & 0.36 \\
\hline Population growth rate $\left(r\right.$, year $\left.^{-1}\right)$ & 0.01 & -0.01 \\
\hline
\end{tabular}


Table 3. Cymodocea nodosa carbon (C) and nitrogen $(\mathrm{N})$ content and ratios (means $\pm \mathrm{SE}$ ) at $\mathrm{CO}_{2}$ seeps of Greek (Adamas and Paleochori) and Italy (Vulcano) islands. Tukey's multiple comparison $(\mathrm{p}<0.05)$ test results are presented. Differences between sites (Adamas vs Paleochori-A, Adamas vs Vulcano-B, Vulcano vs Paleochori-C) and stations $\left(\mathrm{CO}_{2}\right.$ seeps and reference) are indicated by capital letters and small letters respectively. No difference between sites are presented by $\mathrm{X}$

\begin{tabular}{|c|c|c|c|c|c|c|c|}
\hline \multirow[t]{2}{*}{ Variables } & & \multirow{2}{*}{$\begin{array}{l}\text { Adamas } \\
\mathrm{CO}_{2} \text { seeps }\end{array}$} & \multirow[b]{2}{*}{ Reference } & \multirow{2}{*}{$\begin{array}{l}\text { Paleochori } \\
\mathrm{CO}_{2} \text { seeps }\end{array}$} & \multirow[b]{2}{*}{ Reference } & \multirow{2}{*}{$\begin{array}{l}\text { Vulcano } \\
\mathrm{CO}_{2} \text { seeps }\end{array}$} & \multirow[b]{2}{*}{ Reference } \\
\hline & & & & & & & \\
\hline \multirow[t]{2}{*}{$\mathrm{C}(\% \mathrm{DW})$} & Leaves & $35.0 \pm 0.19^{\mathrm{Ba}}$ & $31.9 \pm 0.70^{\mathrm{Bb}}$ & $35.0 \pm 0.80^{\mathrm{Cc}}$ & $35.2 \pm 0.51^{\mathrm{Cc}}$ & $41.9 \pm 0.62^{\mathrm{BCd}}$ & $41.3 \pm 0.03^{\mathrm{BCd}}$ \\
\hline & Roots & $35.3 \pm 0.47^{\mathrm{ABa}}$ & $34.1 \pm 0.25^{\mathrm{ABa}}$ & $31.9 \pm 0.71^{\mathrm{Ab}}$ & $33.0 \pm 0.42^{\mathrm{BCb}}$ & $30.5 \pm 0.40^{\mathrm{BXc}}$ & $28.8 \pm 0.6^{\mathrm{CXc}}$ \\
\hline $\mathbf{N}(\% \mathrm{DW})$ & Roots & $0.9 \pm 0.17^{\mathrm{Xa}}$ & $0.9 \pm 0.11^{\mathrm{Xa}}$ & $0.8 \pm 0.11^{\mathrm{Xb}}$ & $1.0 \pm 0.07^{\mathrm{Xb}}$ & $0.8 \pm 0.02^{\mathrm{Xc}}$ & $1.0 \pm 0.1^{\mathrm{Xc}}$ \\
\hline \multirow[t]{2}{*}{$C: N$} & Leaves & $18.7 \pm 0.12^{\mathrm{Aa}}$ & $18.1 \pm 0.36^{\mathrm{Ab}}$ & $20.9 \pm 0.80^{\mathrm{ACc}}$ & $15.3 \pm 0.37^{\mathrm{Ad}}$ & $16.4 \pm 0.28^{\mathrm{Ce}}$ & $17.5 \pm 0.6^{\mathrm{Ce}}$ \\
\hline & Rhizomes & $20.5 \pm 0.24^{\mathrm{Aa}}$ & $23.5 \pm 0.85^{\mathrm{Aa}}$ & $34.2 \pm 0.63^{\mathrm{ACb}}$ & $33.0 \pm 0.42^{\mathrm{Xc}}$ & $23.5 \pm 1.68^{\mathrm{Cc}}$ & $26.3 \pm 1.0^{\mathrm{Xd}}$ \\
\hline
\end{tabular}




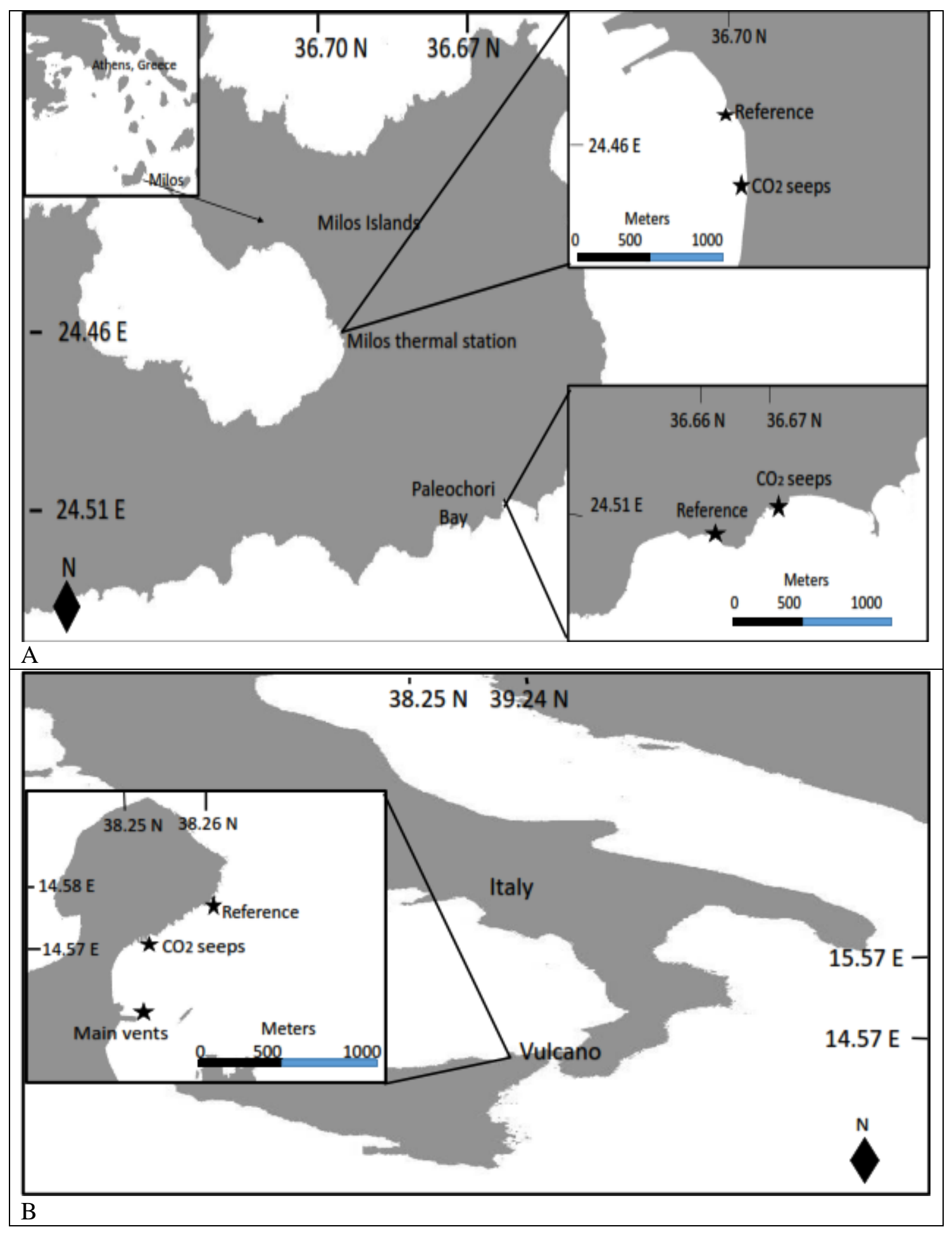

Fig. 1. Study sites with location of $\mathrm{CO}_{2}$ seeps and Reference sites, A) Adamas and Paleochori off Greece and B) Vulcano island off Italy 


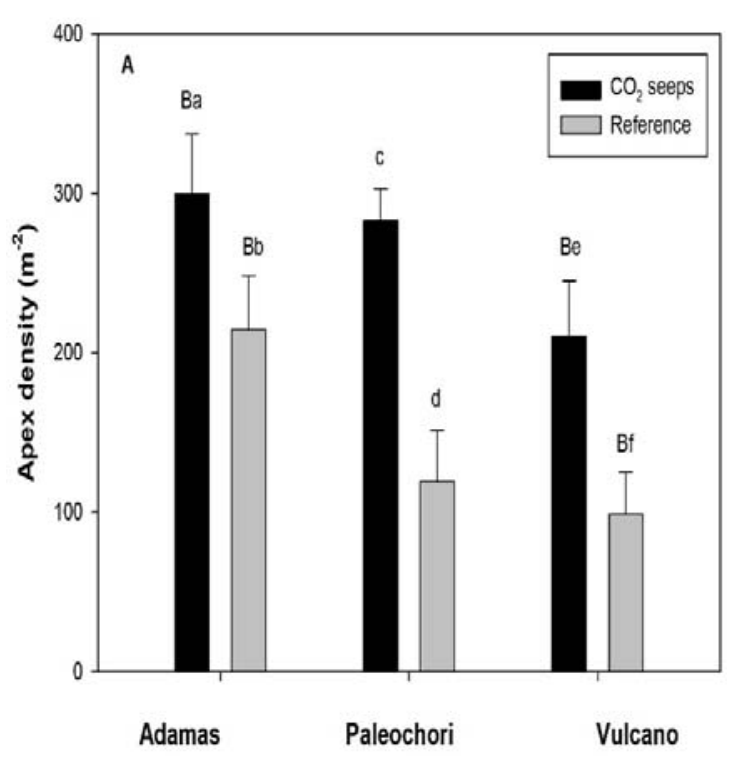

a

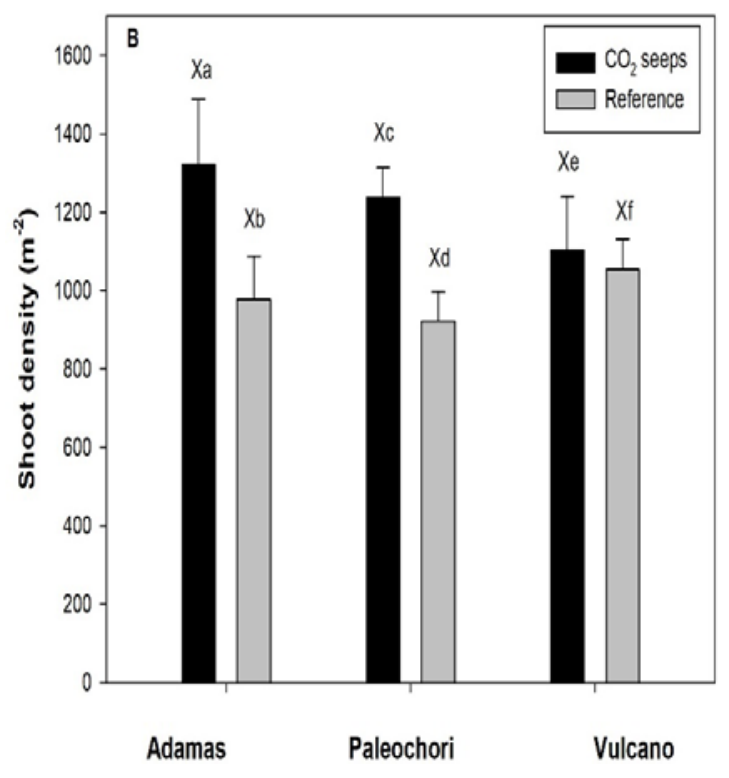

b

Fig.2. Density (Apex and Shoot) of Cymodocea nodosa at the $\mathrm{CO}_{2}$ seeps off the Greek (Adamas and Paleochori) and Italy (Vulcano) islands. Error bars represent standard errors. Differences between sites (Adamas vs Paleochori-A, Adamas vs Vulcano-B, Vulcano vs Paleochori-C) and stations $\left(\mathrm{CO}_{2}\right.$ seeps and reference) are indicated by capital letters and small letters respectively.

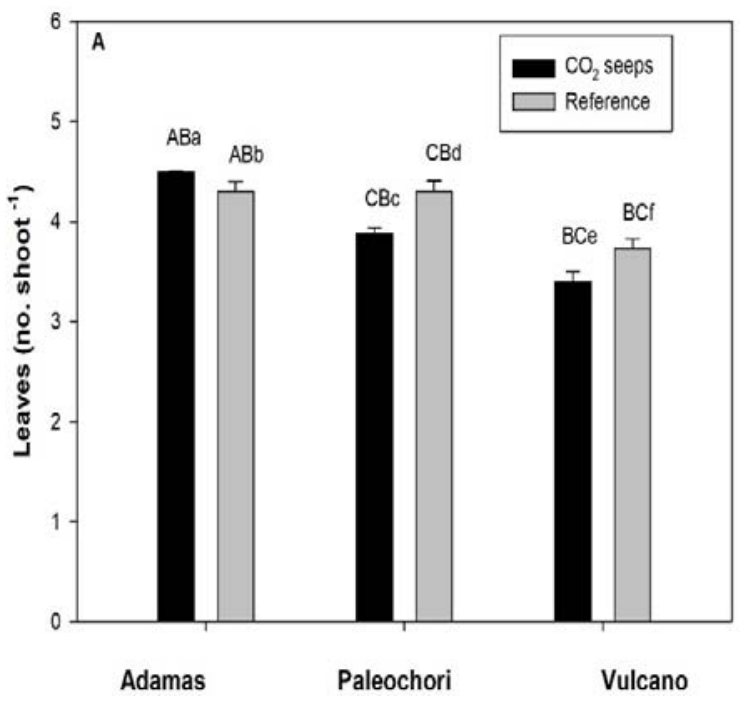

a

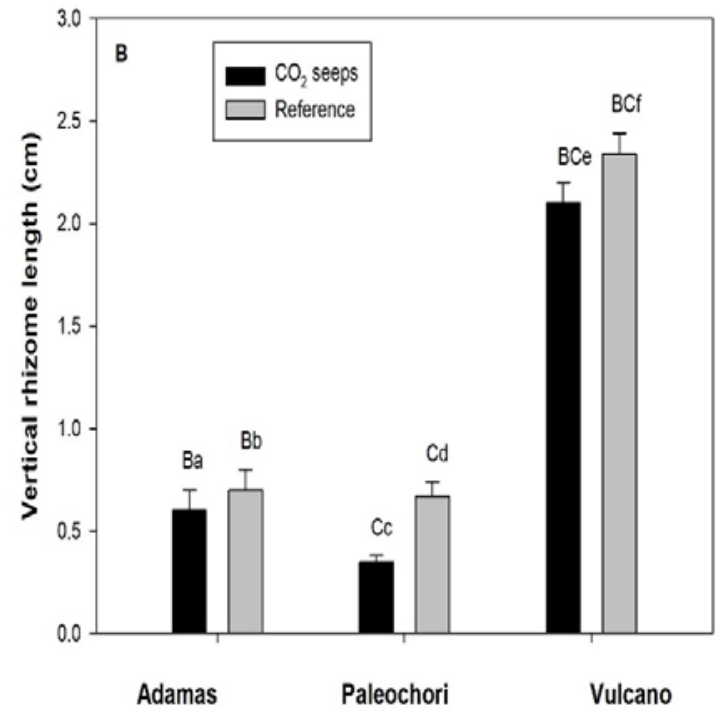

b

Fig.3. Morphometry (Number of Leaves and Vertical rhizome length) of Cymodocea nodosa at $\mathrm{CO}_{2}$ seeps and reference sites off Greek (Adamas and Paleochori) and Italy (Vulcano) islands. Error bars represent standard errors. Differences between sites (Adamas vs 
Paleochori-A, Adamas vs Vulcano-B, Vulcano vs Paleochori-C) and stations $\left(\mathrm{CO}_{2}\right.$ seeps and reference) are indicated by capital letters and small letters respectively.
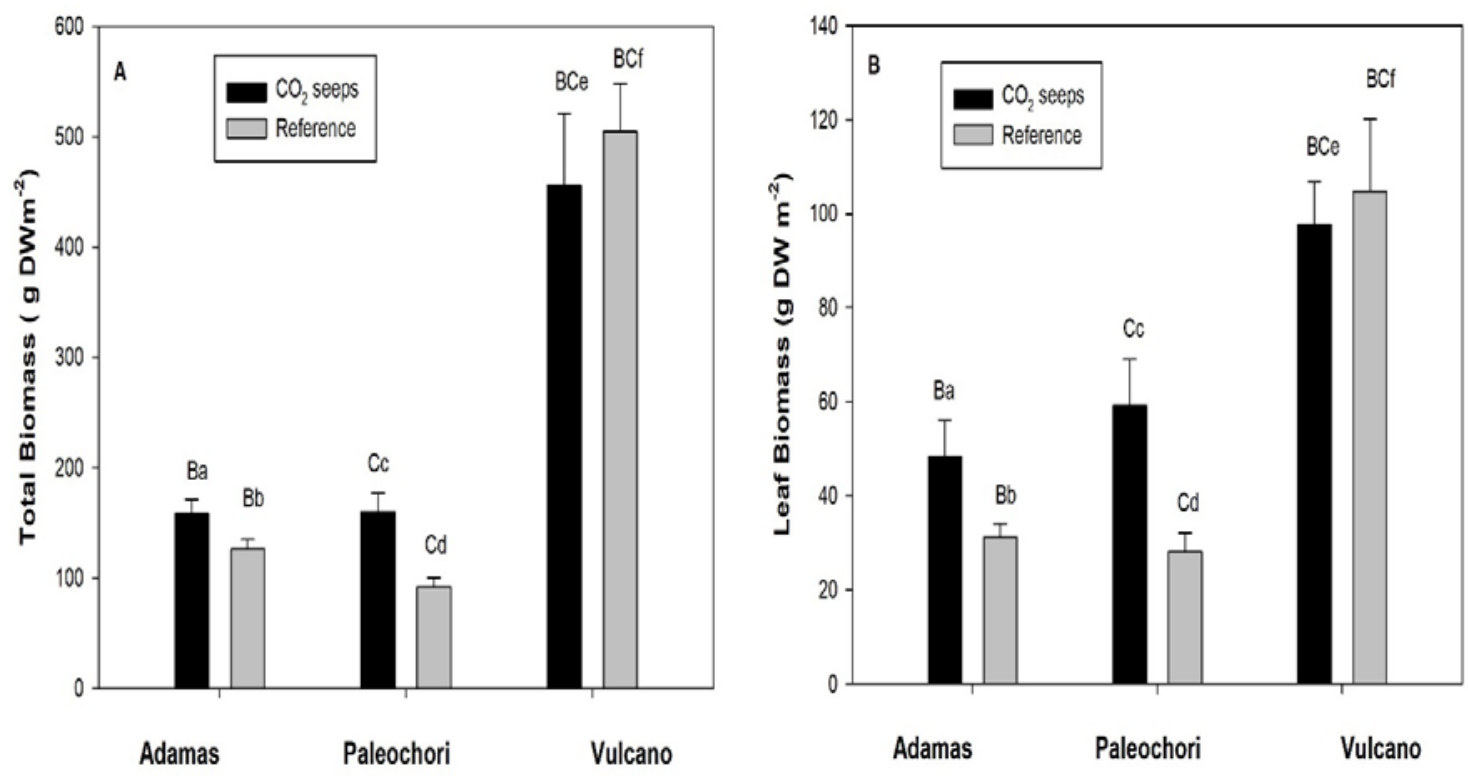

a

b
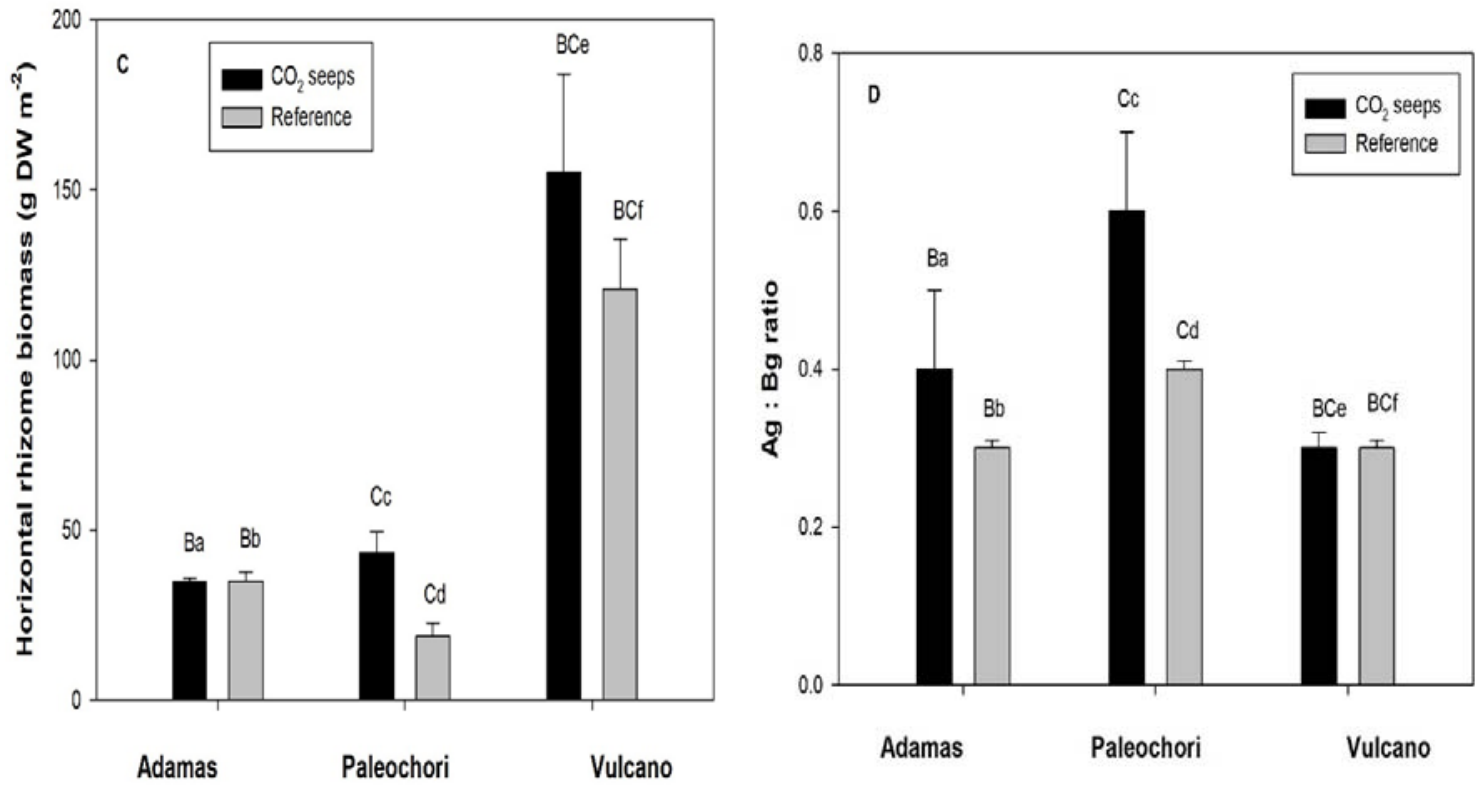

C

d

Fig. 4. Biomass of Cymodocea nodosa at the $\mathrm{CO}_{2}$ seeps and reference sites off Greek (Adamas and Paleochori) and Italy (Vulcano) islands. Error bars represent standard errors. Differences between sites (Adamas vs Paleochori-A, Adamas vs Vulcano-B, Vulcano vs 
Paleochori-C) and stations $\left(\mathrm{CO}_{2}\right.$ seeps and reference) are indicated by capital letters and small letters respectively (Ag: $\mathrm{Bg}$; Above ground biomass: Below ground biomass)

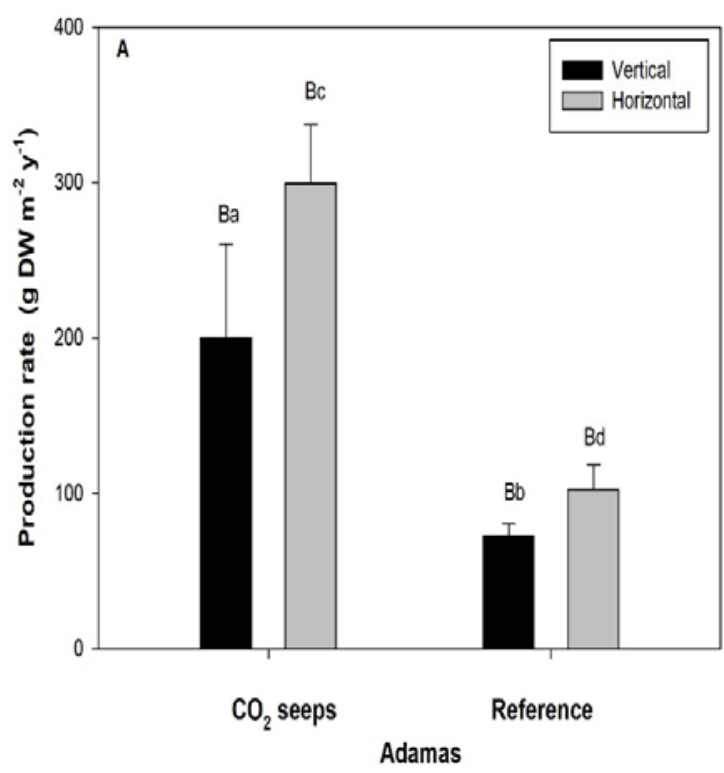

a

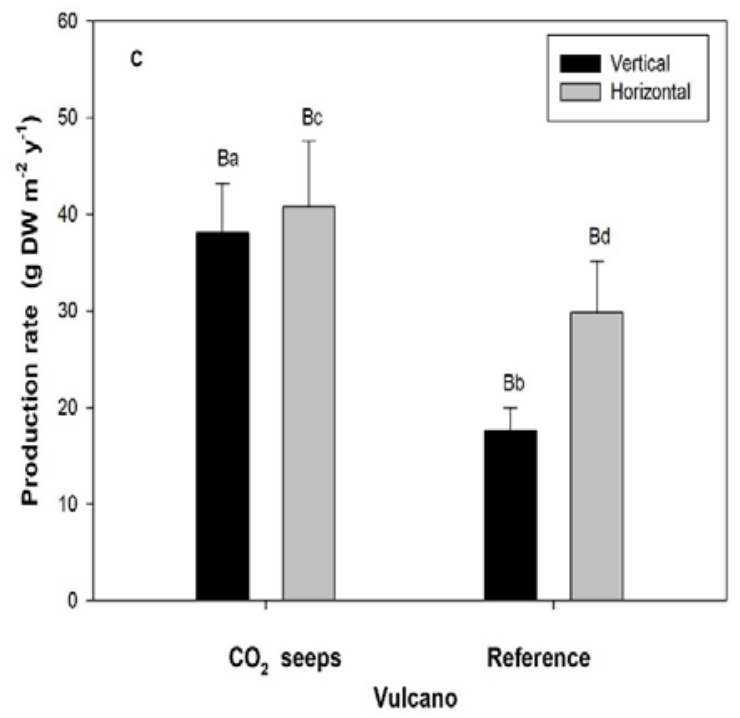

c

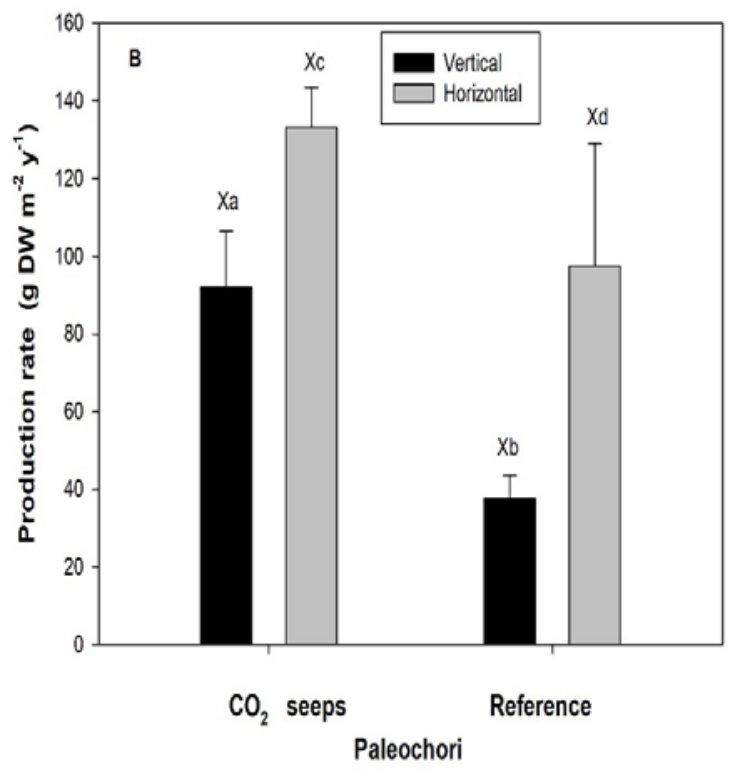

b

Fig.5. Vertical and horizontal rhizome productions of Cymodocea nodosa at the $\mathrm{CO}_{2}$ seeps and reference sites of Greek (Adamas and Paleochori) and Italy (Vulcano) islands. Error bars represent standard errors. Differences between sites (Adamas vs Paleochori-A, Adamas vs Vulcano-B, Vulcano vs Paleochori-C) and stations $\left(\mathrm{CO}_{2}\right.$ seeps and reference) are indicated by capital letters and small letters respectively. No difference between sites are indicated by X. 


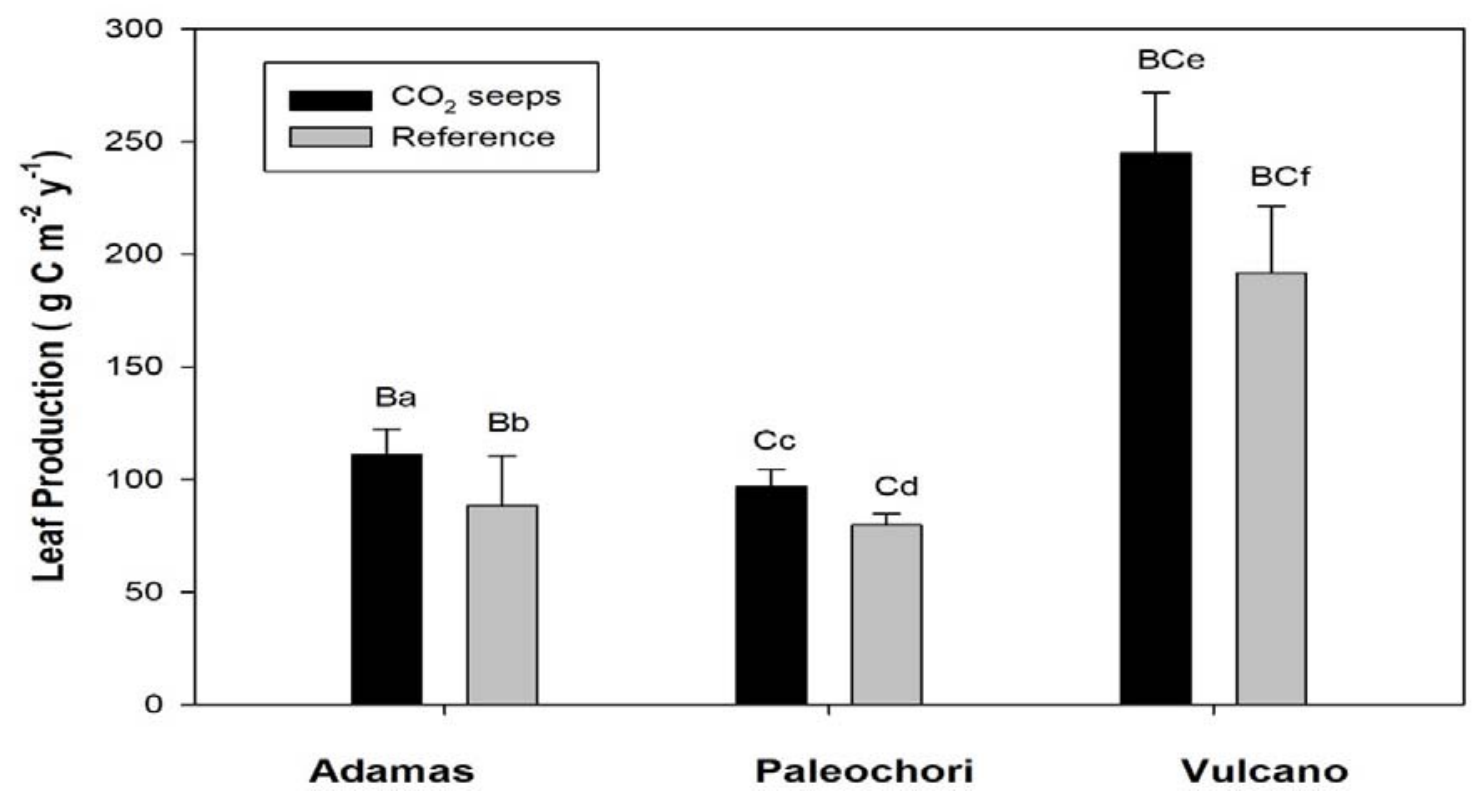

Fig.6. Annual leaf Production of Cymodocea nodosa at the $\mathrm{CO}_{2}$ seeps and reference sites off Greek (Adamas and Paleochori) and Italy (Vulcano) islands. Error bars represent standard errors. Differences between sites (Adamas vs Paleochori-A, Adamas vs Vulcano-B, Vulcano vs Paleochori-C) and stations $\left(\mathrm{CO}_{2}\right.$ seeps and reference) are indicated by capital letters and small letters respectively.

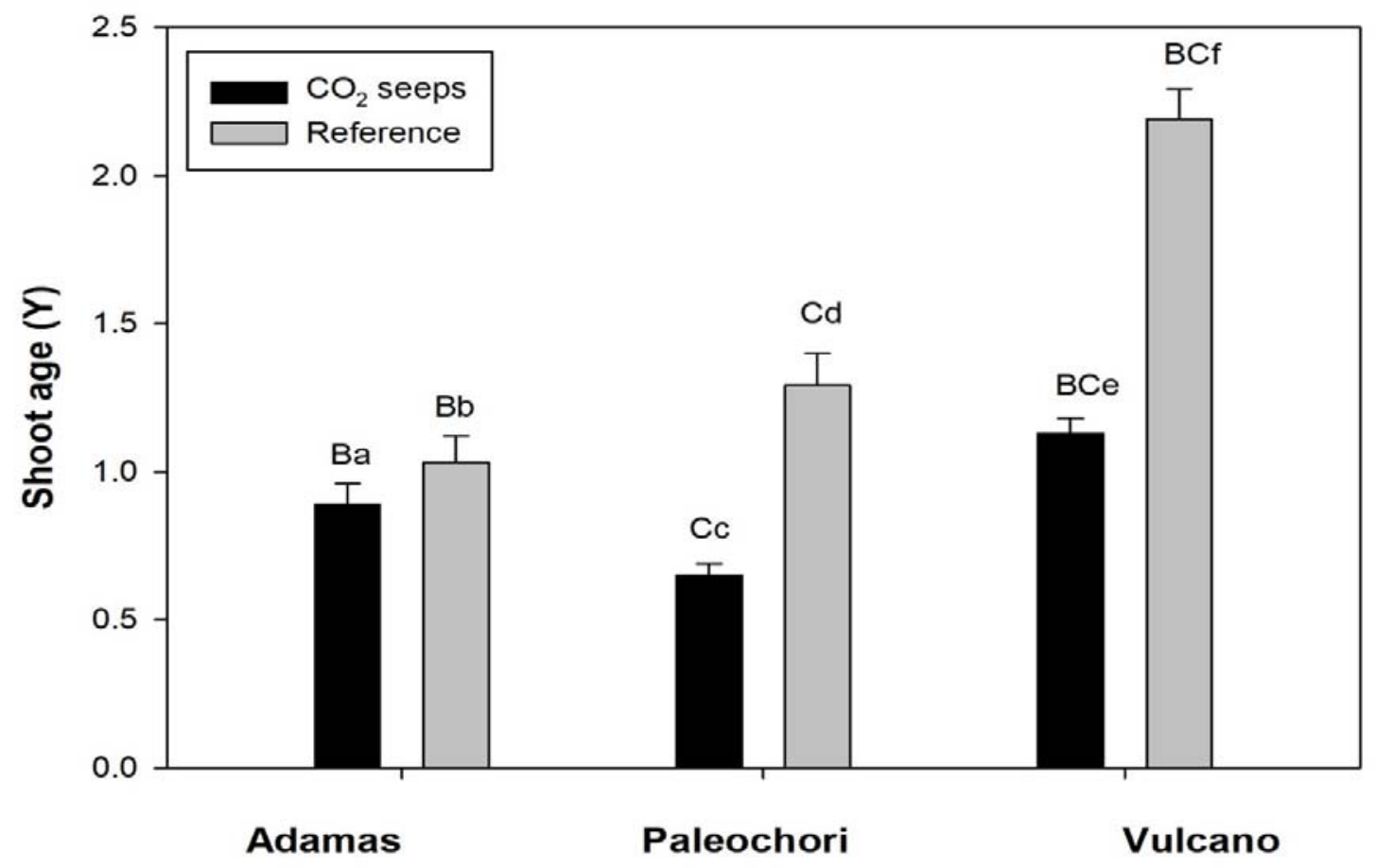

Fig.7. Shoot age of Cymodocea nodosa at the $\mathrm{CO}_{2}$ seeps and reference sites off Greek (Adamas and Paleochori) and Italy (Vulcano) islands. Error bars represent standard errors. Differences between sites (Adamas vs Paleochori-A, Adamas vs Vulcano-B, Vulcano vs 
Paleochori-C) and stations $\left(\mathrm{CO}_{2}\right.$ seeps and reference) are indicated by capital letters and small letters respectively.
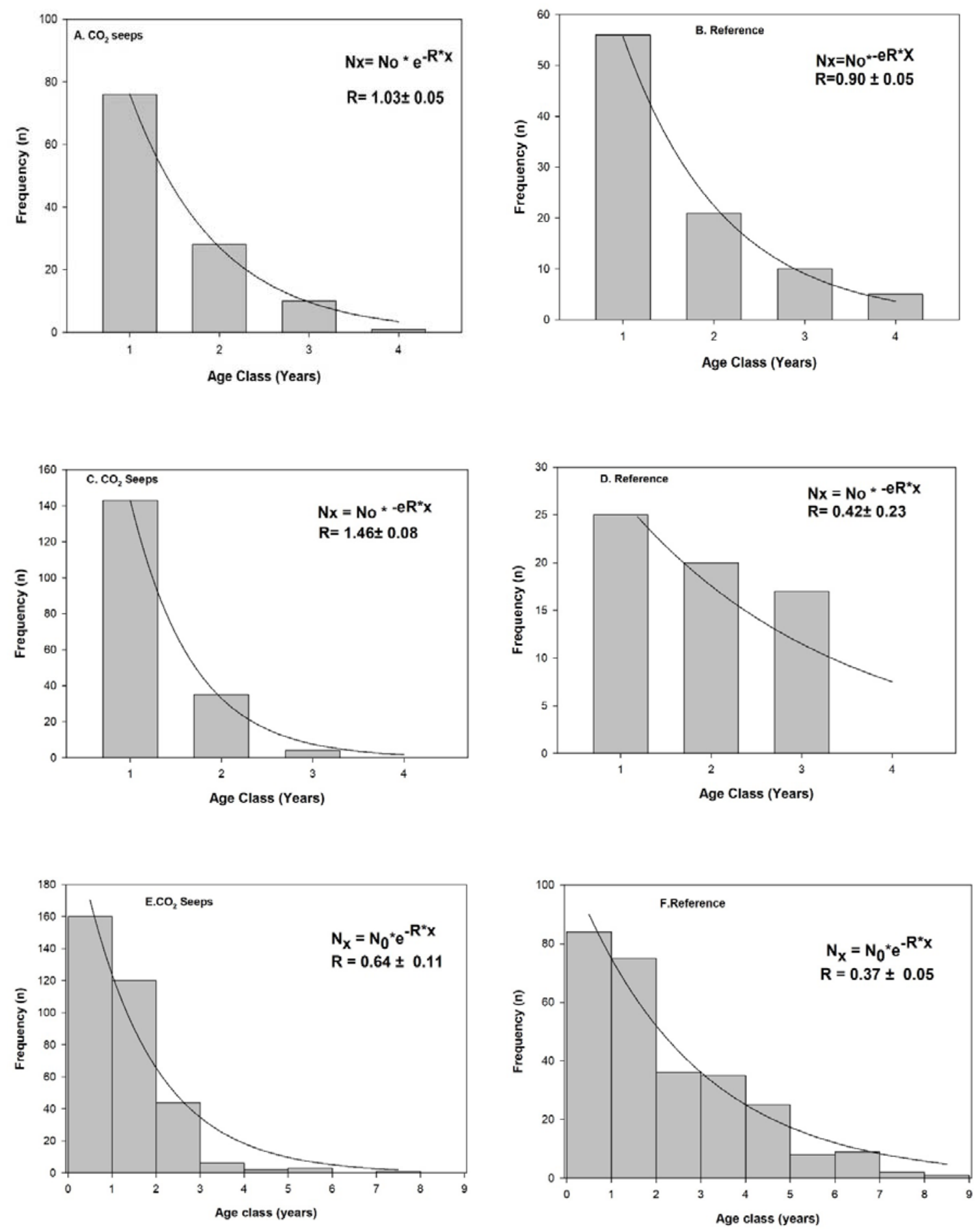

Fig. 8. Age frequency distribution of Cymodocea nodosa population along the $\mathrm{CO}_{2}$ seeps and reference sites off Adamas (a, b), Paleochori $(c, d)$ and Vulcano $(e, f)$ respectively. The long- 
term average recruitment rate $(\mathrm{R})$ was estimated from the exponential decay regression line fitted to age frequency distribution.

\section{Acknowledgement:}

This work was part of MARES "Future Oceans" project (MARES _12_14) and was funded through a MARES Grant. MARES is a Joint Doctorate programme selected under Erasmus Mundus coordinated by Ghent University (FPA 2011-0016). Check www.mares-eu.org for extra information. We are grateful for the support of Thanos Dailianis, Julius Glampedakis and Veronica Santinelli in field sampling and laboratory works respectively at HCMR, Greece.

\section{References:}

Alexandre, A, Silva, J., Buapet, P., Bjork, R., and Santos, R., 2012. Effects of $\mathrm{CO}_{2}$ enrichment on photosynthesis, growth and nitrogen metabolism of the seagrass Zostera noltii. Eco. and Evol.10: 2620-2630

Brierley. S. A., Kingsford, J.M., 2009. Impacts of climate change on marine organisms and ecosystems. Curr. Bio. 14: 602-604.

Beer, S., and Koch, E., 1996. Photosynthesis of marine macro algae and seagrasses in globally changing $\mathrm{CO}_{2}$ environments. Mar. Eco. Prog. Ser. 141:199-204

Boatta, F., D’Alessandro, W., Gagliano, A.L., Liotta, M., et al., 2013. Geochemical survey of Levante bay, Vulcano island (Italy), a natural laboratory for the study of ocean acidification. Mar. Pollut. Bull. 73: 485-494

Cabaço, S., Santos, R., Duarte, C.M., 2008. The impact of sediment burial and erosion seagrasses: A review. Estu. Coast. and Shelf Sci.79: 354-366.

Campbell, J.E., Fourqurean, J.W., 2013. Effects of in situ $\mathrm{CO}_{2}$ enrichment on the structural and chemical characteristics of the seagrass Thalassia testudinum. Mar. Bio. 160: 1465-1475

Caldeira, K., and Wickett, M.E., 2003. Oceanography: anthropogenic carbon and ocean pH. Nature. 425:365.

Capaccioni, B., Tassi, F., Vaselli, O., 2001. Organic and inorganic geochemistry of low temperature gas discharges at the Baia di Levante beach, Vulcano Island, Italy. J. Volcanol. Geoth. Res. 108: 173-185.

Cunha, A.H., Duarte, C.M., 2005. Population age structure and rhizome growth of Cymodocea nodosa in the Ria Formosa (southern Portugal). Mar. Bio. 146: 841-847.

den Hartog, C., 1970. The Seagrasses of the World. North Holland Publication., Amsterdam, 275pp.

Dando, P. R., Stuben, D., \& Varnavas, S. P., 1999. Hydrothermalism in the Mediterranean Sea. Prog. in Oceano. 44: 333-367.

Dando, P., Aliani, S., Arab, H., Bianchi, C., Brehmer, M. et al., 2000. Hydrothermal studies in the Aegean Sea. Phys. Chem. Earth B. Hydrol. Oceans Atmos. 25: 1-8 
Dickson, A.G., Wolf-Gladrow, D. A., Zeebe, R.E., Klaas, C., Kortzinger, A., 2007. Total alkalinity: The explicit conservative expression and its application to biogeochemical processes. Mar. Chem. 106: 287-300.

Duarte, C.M., Marbà, N., Agawin, N., Cebrián, J., Enríquez, S. et al., 1994. Reconstruction of seagrass dynamics: age determinations and associated tools for the seagrass ecologist. Mar. Eco. Prog. Ser. 107: 195-209.

Duarte, C.M., Sand-Jensen, K., 1990. Seagrass colonization: biomass development and shoot demography in Cymodocea nodosa patches. Mar. Eco. Prog. Ser. 67: 97-103.

Duarte, M. C., 1990. Seagrass nutrient content. Mar. Eco. Prog. Ser. 67: 201-207.

Dekov, V.M., Savelli, C., 2004. Hydrothermal activity in the SE Tyrrhenian Sea: an overview of 30 years of research. Mar. Geol. 204: 161-185.

Enochs, I.C., Manzello, D.P., Donham, E.M., Kolodziej, G., Okano, R., et al., 2015. Shift from coral to macroalgae dominance on a volcanically acidified reef. Nat. Clim. Change. 5: 1083-1088.

Eugenia, T.A., Vizzini, S., Hendriks, I.E., Olsen, Y.S., 2014. Seagrass ecosystem response to long term high $\mathrm{CO}_{2}$ in a Mediterranean volcanic vent. Mar. Env. Res. 99: 9-15.

Fabricius, K.E., Langdon, C., Uthicke, S., Humphrey, C., Noonan, S., et al. 2011b. Losers and winners in coral reefs acclimatized to elevated carbon dioxide concentrations. Nat. Clim. Change. 1: 165-169

Feely, R. A., Sabine, C. L., Lee, K., Berelson, W., et al., 2004. Impact of anthropogenic $\mathrm{CO}_{2}$ on the $\mathrm{CaCO}_{3}$ system in the oceans. Science 305:362-366

Fourqurean, W.J., Duarte, C.M., Marba. N., 2003. Elucidating seagrass population dynamics: Theory, constraints and practice. Limnol. Oceano. 48: 2070-2074.

Gianluigi, C., Buia, M.C., Mazzella, L., 2002. Structure and growth dynamics of Cymodocea nodosa meadows. Sci. Mar. 66: 365-373.

Hall-Spencer, J.M., Rodolfo-Metalpa, R., Martin, S., Ransome, E., et al., 2008. Volcanic carbon dioxide seeps show ecosystem effects of ocean acidification. Nature. 454: 96-99.

Hall-Spencer, J.M., Rodolfo-Metalpa, R.A.B., 2009. Using scientific diving to investigate the long-term effects of ocean acidification at $\mathrm{CO}_{2}$ seeps. Online Geosci. 22: $72-76$

Hemminga, M.A., Duarte, C.M., 2000. Seagrass Ecology. Cambridge University Press, Cambridge. 289 pp.

Hendriks, I. E., Duarte, C.M., Alvarez, M., 2010. Vulnerability of marine biodiversity to ocean acidification: a meta-analysis. Estu. Coastal and Shelf Sci. 86: 157-164.

International Panel for Climate Change (IPCC). 2014. Fifth Assessment Report on Climate change: Impacts, Adaptation and Vulnerability.

Invers, O., Zimmerman, R.C., Alberte, R.S., Perez, M., et al., 2001. Inorganic carbon sources for seagrass photosynthesis: an experimental evaluation of bicarbonate use in species inhabiting temperate waters. J. of Exp. Mar. Bio. Eco. 265: 203-217

Inguaggiato, S., Mazot, A., Diliberto, I.S., Inguaggiato, C., et al., 2012. Total $\mathrm{CO}_{2}$ output from Vulcano Island (Aeolian Islands, Italy). Geochem. Geophys. Geosyst. 
Jiang, Z.J., Huang, X.P., Zhang, J.P., 2010. Effects of $\mathrm{CO}_{2}$ enrichment on photosynthesis, growth, and biochemical composition of seagrass Thalassia hemprichii (Ehrenb.) Aschers. J. of Int. Plant Bio. 52: 904-913.

Kádár, E., Costa, V., Segonzac, M., 2007. Trophic influences of metal accumulation in natural pollution laboratories at deep-sea hydrothermal seeps of the Mid- Atlantic Ridge. Sci. Tot. Environ. 373: 464-472.

Khan, F., Alexandre, A., Ullah, H., Santos, R., 2016. Effects of elevated $\mathrm{CO}_{2}$ and nutrients on the community metabolism of a Cymodocea nodosa bed. Turk. J. of Bot. 40: 250-257

Koch, M., Bowes, G., Ross, C., Zhang, X., 2013. Climate change and ocean acidification effects on seagrasses and marine macro algae. Glo. Change Bio. 19: 103-132

Kroeker, K. J., Kordas, R. L., Crim, R.N., Singh, G. G., 2010. Meta-analysis reveals negative yet variable effects of ocean acidification on marine organisms. Eco. Let. 13: 1419-1434

Kraemer, G.P., Mazzella, L., 1999. Nitrogen acquisition, storage, and use by the co-occurring Mediterranean seagrasses Cymodocea nodosa and Zostera noltii. Mar. Eco. Prog. Ser. 183: 95-103.

Marbà, N., Cebrián, J., Enríquez, S., Duarte, C.M., 1994. Migration of large-scale subaqueous bed forms measured with seagrasses (Cymodocea nodosa) as tracers. Lim. and Oceano. 39: 126-133.

Marbà, N., Duarte, C.M., 1994. Growth response of the seagrass Cymodocea nodosa to experimental burial and erosion. Mar. Eco. Prog. Ser. 107: 307-311.

Marbà, N., Duarte, C.M., 1995. Coupling of seagrass (Cymodocea nodosa) patch dynamics to subaqueous dune migration. J. of Eco. 83: 1-9.

Marbà, N., Duarte, C.M., 1998. Rhizome elongation and seagrass clonal growth. Mar. Eco. Prog. Ser. 174: 269-280.

Martin, S., Rodolfo -Metalpa, R., Ransome E., Rowley S., et al., 2008. Effects of naturally acidified seawater on seagrass calcareous epibionts. Bio. Letters. 4: 689-692

Mazzella, L. and Alberte, R.S.,1986. Light adaptation and the role of autotrophic epiphytes in primary production of the temperate seagrass, Zostera marina (L). J. of Exp. Mar. Bio. Eco. 100: $165-180$.

Meehl, G.A., Stocker, T.F., Collins, W.D., Friedlingstein, P., et al., 2007. The Physical Science Basis Contribution of Working Group I to the Fourth Assessment Report of the Intergovernmental Panel on Climate Change. Cambridge University Press.747-845.

Milazzo, M., Rodolfo-Metalpa, R., Chan, V.B.S., Fine, M. et al., 2014. Ocean acidification impairs vermetid reef recruitment. Scienti. Rep. 4 (4189).

Olesen, B., Enríquez, S., Duarte, C.M., Sand-Jensen, K., 2002. Depth-acclimation of photosynthesis, morphology and demography of Posidonia oceanica and Cymodocea nodosa in the Spanish Mediterranean Sea. Mar. Eco. Prog. Ser. 236: 89-97.

Ow. Y.X., Collier. C.J., Uthicke. S., 2015. Response of three tropical seagrass species to $\mathrm{CO}_{2}$ enrichment. Mar. Bio. 162: 1005-1017. 
Palacios, S.L., Zimmerman, R.C., 2007. Response of eelgrass Zostera marina to $\mathrm{CO}_{2}$ enrichment: possible impacts of climate change and potential for remediation of coastal habitats. Mar. Eco. Prog. Ser. 344: 1-13

Perez, M., Duarte, C.M., Romero, J., Sand-Jensen, K., et al., 1994. Growth plasticity in Cymodocea nodosa stands: the importance of nutrient supply. Aq. Bot. 47: 249-264.

Pierrot, D. E. L., and Wallace, D. W. R., 2006. MS Excel Program Developed for $\mathrm{CO}_{2}$ System Calculations. ORNL/CDIAC-105a. Carbon Dioxide Information Analysis Centre, Oak Ridge National Laboratory, US Department of Energy, Oak Ridge, TN.

Russell, B.D., Connell, S.D., Uthicke, S., Muehllehner, N., et al., 2013. Future seagrass beds: can increased productivity lead to increased carbon storage? Mar. Pollut. Bull. 73: 463-469

Schwarz, A.M., Bjork, M., Buluda, T., Mtolera, H., et al., 2000. Photosynthetic utilisation of carbon and light by two tropical seagrass species as measured in situ. Mar. Biol. 137: 755761

Short, F.T., Coles, R.C., 2001. Global Seagrass Research Methods. Elsevier Science, B.V., Amsterdam, $473 \mathrm{pp}$.

Sokal, R. R. and Rohlf, F.J., 2012. Biometry: the principles and practice of statistics in biological research. 4th edition. W. H. Freeman and Co.: New York. 937 pp.

Suggett. D.J., Hall-Spencer, J.M., R Metalpa, R., Boatman, R.G., et al., 2012. Sea anemones may thrive in a high $\mathrm{CO}_{2}$ world. Global Change Bio. 18: 3015-3025.

Takahashi. M., Noonan. S. H. C., Fabricius. K. E., Collier. C. J., 2016. The effects of longterm in situ $\mathrm{CO}_{2}$ enrichment on tropical seagrass communities at volcanic seeps. ICES J. of Mar. Sci. 73: 876-886.

Valiela, I., McClelland, J., Hauxwell, J., Behr, P.J., et al., 1997. Macroalgal blooms in shallow estuaries: References and Ecophysiological Ecosystem Consequences. Limnol. and Oceano. 42: 1105-1118

Varnavas, S.P., Cronan, D.S., 2005. Submarine hydrothermal activity off Santorini and Milos in the Central Hellenic Volcanic Arc: a synthesis. Chem. Geol. 224: 40-54.

Vizzini, S., Tomasello, A., Maida, G.D., Pirrotta, M., et al., 2010. Effects of shallow hydrothermal seeps on the $\delta 13 \mathrm{C}$ and growth performance in the seagrass Posidonia oceanica. J. of Eco. 98: 1284-1291.

Vizzini, S., Valentina, C., Cecilia, T., Paola, G. et al., 2013. Trophic Transfer of Trace Elements in an Isotopically Constructed Food Chain from a Semi-Enclosed Marine Coastal Area (Stagnone di Marsala, Sicily, Mediterranean). Arch. Environ. Contam. Toxicol. 65: 642-653

Welsh, D., Bourgues, S., de Wit, R., Auby, I., 1997. Effect of plant photosynthesis, carbon sources and ammonium availability on nitrogen fixation rates in the rhizosphere of Zostera noltii. Aq. Micro. Eco. 12:285-290

Zimmerman. R. C., Kohrs. D.G., Steller. D.L., Alberte. R.S., 1997. Impacts of $\mathrm{CO}_{2}$ enrichment on Productivity and Light requirements of Eelgrass. Plant Physio. 115: 599-607. 